\title{
Role of gap junctions during early embryo development
}

\author{
Franchesca D Houghton \\ Department of Biology (Area 3), University of York, PO Box 373, York YO10 5YW, USA \\ Correspondence should be addressed to F D Houghton; Email: fdh1@york.ac.uk
}

\begin{abstract}
Gap junctional communication plays a central role in the maintenance of cellular homeostasis by allowing the passage of small molecules between adjacent cells. Gap junctions are composed of a family of proteins termed connexins. During preimplantation development several connexin proteins are expressed and assembled into gap junctions in the plasma membrane at compaction but the functional significance of connexin diversity remains controversial. Although, many of the connexin genes have been disrupted using homologous recombination in embryonic stem cells to obtain unique phenotypes, none of these studies has demonstrated a specific role for connexins during preimplantation development in the null mutants. This review surveys evidence for the involvement of gap junctional communication during embryo development highlighting discrepancies in the literature. Although some evidence suggests that gap junctions may be dispensable during preimplantation development this is difficult to envisage particularly for the process of cavitation and the maintenance of homeostasis between the differentiated trophectoderm cells and the pluripotent inner cell mass cells of the blastocyst.
\end{abstract}

Reproduction (2005) 129 129-135

\section{Gap-junction structure}

Gap junctions maintain cellular homeostasis by allowing communication between adjacent cells. They span the plasma membrane of two adjacent cells (Makowski et al. 1977), with each cell contributing half the channel; a hemichannel, or connexon. A connexon from one cell docks in the extracellular space with a connexon from an opposing cell to form a complete gap-junction channel, allowing adjacent cells to be coupled (reviewed by Bruzzone et al. 1996a). Each connexon is a multimeric assembly of six proteins, termed connexins (Fig. 1). Connexons may be composed of the same type of connexin, termed homomeric, or contain multiple connexins, termed heteromeric connexons. The docking of two homomeric connexons composed of the same connexin protein yields a homotypic channel, whereas the oligomerization of two homomeric connexins composed of different connexins forms a heterotypic channel (Revel \& Karnovsky 1967, Makowski et al. 1977, Unwin \& Zampighi 1980, Casio et al. 1995). Studies using atomic force microsopy have shown that liver gap junctions are densely packed with a centre-to-centre distance of $9-10 \mathrm{~nm}$ and an average pore size of $3.9 \mathrm{~nm}$ (Hoh et al. 1993, Lal et al. 1995). Each connexon forms a cylinder with a pore in the centre through which molecules of less than $1000 \mathrm{Da}$, such as metabolites, ions and second messengers, can pass, thus facilitating homeostasis (reviewed by Bruzzone et al. 1996a).
Currently 19 rodent and 20 human connexins have been characterized (Willecke et al. 2002). They vary in both the properties of the channels they form as well as their distribution among adult cell types, with most cells expressing more than one connexin type. Connexins are integral membrane proteins containing four transmembrane, two extracellular and three intracellular domains. The intracellular domains, which contain both the $\mathrm{C}$ - and $\mathrm{N}$-terminal segments and intracellular loop, are targets for posttranslational modifications, important for the regulation of channel activity. The extracellular domains are required for connexon docking. Connexins are classified according to their molecular mass (Beyer et al. 1987). For example, connexin (Cx) 43 has a predicted molecular mass of $43 \mathrm{kDa}$ and $\mathrm{C} \times 31$ has a predicted molecular mass of $31 \mathrm{kDa}$. Coexpression of connexins is common; hepatocytes express both Cx26 and Cx32 (Nicholson et al. 1987), as do proximal kidney tubule cells (Butterweck et al. 1994), whereas vascular endothelium co-expresses Cx37 and Cx40 (Delorme et al. 1997). Gap junctions composed of different connexins have different rates of diffusion for specific molecules (reviewed by Koval 2002). For example, Cx43 channels are 120-160-fold more permeable to ADP and/or ATP than Cx32 channels (Goldberg et al. 1999). In addition, the formation of heterotypic gap junctions enables unique permeability characteristics to be obtained compared to homotypic channels. Channels composed of Cx32 allow the passage of CGMP and CAMP whereas heteromeric 


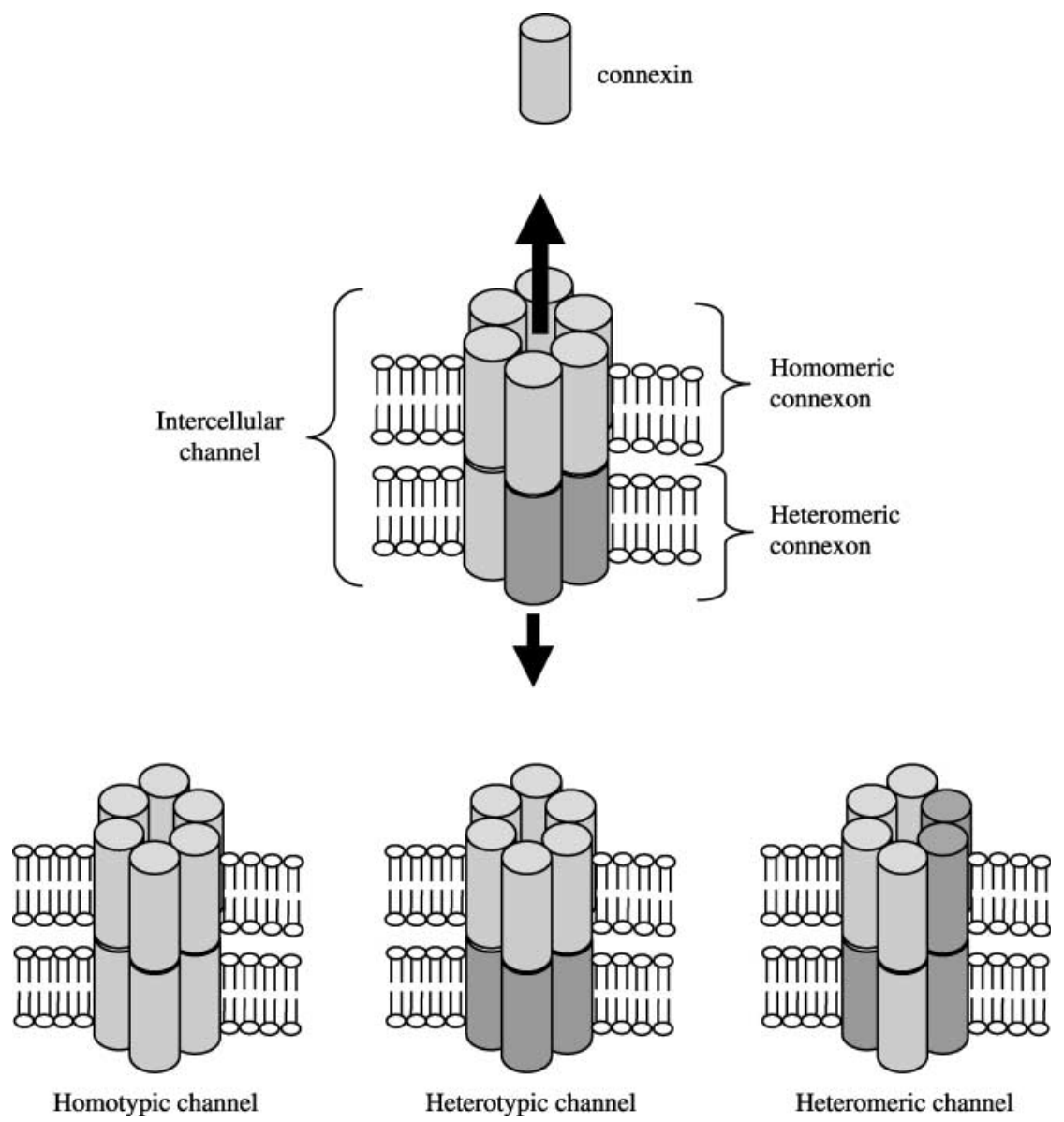

Figure 1 Schematic diagram depicting intercelluar junctions. Six connexin proteins are assembled to form a connexon. A connexon from one cell docks with a connexon from an apposing plasma membrane to form an intercellular channel. Connexons may be homomeric, composed of a single connexin protein, or heteromeric, containing multiple connexins. Oligomerization of different types of connexons may form homotypic, heterotypic or heteromeric channels.

Cx32 and $\mathrm{C} \times 26$ channels are preferentially permeable to cGMP compared to cAMP (Bevans et al. 1998); however, the mechanism of action has yet to be determined.

\section{Connexin expression in preimplantation embryos}

Connexin mRNA expression patterns vary during murine preimplantation development with Cx30, Cx31, Cx36, Cx43, Cx45 and Cx57 being expressed from the two- to four-cell stage, and Cx30.3, Cx31.1 and Cx40 from the eight-cell stage (Davies et al. 1996, Houghton et al. 2002). Connexin proteins tend to be translated shortly after mRNA expression but are located initially in the cytoplasm. Once cell adhesion between blastomeres has occurred at the eight-cell stage, in the process of compaction (reviewed by Fleming et al. 2001), Cx43 begins to traffick to the plasma membrane for assembly into gap junctions (De Sousa et al. 1993). It has been shown that although compaction and gap-junction formation in embryos are independent events, they are temporally correlated (Kidder et al. 1987). Appreciation of the involvement of cell-adhesion molecules in gap-junction formation arises from work using a mouse sarcoma cell line (S180). These cells express Cx43 but fail to display coupling unless they are transfected with E-cadherin, a calcium-dependent cell-adhesion molecule (Mege et al. 1988) that is also observed in other cell types (Jongen et al. 1991). It is likely that the control of gap-junctional intercellular communication by E-cadherin involves posttranslational regulation (assembly and/or function) of the gap-junction protein Cx43 (Musil et al. 1990).

Human preimplantation embryos express predominantly Cx43 and protein levels increase throughout development to the blastocyst stage (Hardy et al. 1996). This finding was confirmed and extended at the mRNA level where $\mathrm{Cx} 31$ and $\mathrm{C} \times 43$ were found to be expressed throughout development; Cx26 and Cx45 showed inconsistent expression, whereas $\mathrm{C} \times 32$ and $\mathrm{C} \times 40$ were not expressed at any stage (Bloor et al. 2004). This is in contrast to Hardy et al. (1996), who found the presence of Cx32 protein in the late human blastocyst. The functional significance of the inconsistently expressed connexin genes has yet to be elucidated. At the blastocyst stage, Cx26, Cx45 and Cx31 showed a reduced level of protein 
expression compared to $\mathrm{Cx} 43$, but displayed coexpression with Cx43 (Bloor et al. 2004).

In the bovine embryo, Cx43 expression varies depending whether the embryos are produced in vitro or in vivo. In vitro, Cx43 was expressed in the oocyte and zygote through to the morula stage but was not expressed at the blastocyst stage, whereas Cx43 transcripts were detected in morula and blastocysts produced in vivo (Wrenzycki et al. 1996). Subsequently, a significant increase in Cx43 mRNA expression was found from the 16-cell stage to the blastocyst stage during in vivo bovine development (Lonergan et al. 2003).

\section{Signalling and gap-junction regulation}

Gap junctions may be regulated by hormones and other extracellular signalling molecules such as neurotransmitters, growth factors and cytokines (Stagg \& Fletcher 1990, Bruzzone et al. 1996b, Sáez et al. 1998). The extent to which cells are coupled depends on several mechanisms: gene transcription, stability of the message, translational and post-translational modifications and assembly of the protein into the membrane (Sáez et al. 1998). Connexin phosphorylation occurs predominantly in the C-terminal domain and is the best-characterized mechanism of regulation, mediated predominantly by protein kinase A (PKA), protein kinase $C$ (PKC), mitogen-activated protein kinases and tyrosine kinase (reviewed by Sáez et al. 1998, Lampe \& Lau 2004). Depending on the cell type, these kinases may either increase or decrease gap-junctional intercellular communication (reviewed by Alves et al. 2000). For example, in bovine lens cells, activation of PKC inhibits gap-junctional communication (Reynhout et al. 1992) whereas in neonatal rat cardiomyocytes activation of PKC increases junctional conductance (Kwak et al. 1995). In the preimplantation embryo, Cx43 is present in the nonphosphorylated form from the mid-four-cell stage with the phosphorylated form increasing from the eight-cell stage onwards (Ogawa et al. 2000). These investigators also found that activation of PKA via dibutyryl-cAMP increased Cx43 phosphorylation and the number of Cx43-positive plaques, whereas a PKC activator, tumour promoter 12-Otetradecanoylphorbol-13-acetate (TPA) increased Cx43 phosphorylation but decreased the number of Cx43-positive plaques. Taken together, these results suggest that phosphorylation is required for gap-junction formation in the embryo and may be facilitated by PKA and inhibited by PKC activation.

\section{Functional significance of connexin diversity}

Although each connexin possesses distinct gating properties and its conductance may be controlled by factors such as $\mathrm{Ca}^{2+}, \mathrm{pH}$ and cAMP, their functional significance during preimplantation development is unknown. In an attempt to explore the functional significance of connexin diversity, a targeted gene-inactivation approach has been used. Several of the murine connexin-encoding genes have now been disrupted using homologous recombination in embryonic stem cells: Cx43 (Reaume et al. 1995), Cx32 (Nelles et al. 1996), Cx37 (Simon et al. 1997), Cx46 (Gong et al. 1997), Cx40 (Simon et al. 1998), Cx26 (Gabriel et al. 1998), Cx50 (White et al. 1998), Cx45 (Kumai et al. 2000), Cx36 (Guldenagel et al. 2001), Cx31 (Plum et al. 2001) and Cx30 (Teubner et al. 2003). Each connexin-null mutant results in a unique phenotype, demonstrating a specific physiological role for that connexin in at least a subset of its expression sites (reviewed by Nicholson \& Bruzzone 1997, White \& Paul 1999). However, these phenotypes are often difficult to interpret due to the potential for redundancy and for other coexpressed connexins to compensate for loss of expression. For example, $\mathrm{Cx} 43$ is expressed in the preimplantation embryo from the two-cell stage onward (De Sousa et al. 1993). Nevertheless, mice lacking Cx43 survive to term, but die shortly afterwards due to a morphological defect in the right-ventricular outflow tract of the heart (Reaume et al. 1995). However, the lack of abnormalities in other tissues is often used as evidence that compensation occurs between connexins, or that there is redundant expression. The possibility that connexins may functionally compensate for one another in cells where they are co-expressed was studied by generating doubly mutant mice, deficient in Cx32 and Cx43. Fetuses lacking both Cx43 and Cx32 survived to term but died shortly afterwards from the same cardiac abnormality associated with the Cx43 deficiency. No morphological abnormalities were observed in the limbs, thyroid gland or developing teeth, the major sites where the two connexins are co-expressed (Houghton et al. 1999).

\section{Gap junctions and preimplantation development}

Whether or not there is a functional requirement for gap junctions in preimplantation development is controversial. Becker et al. (1995) raised several anti-Cx43 antibodies to different regions of the protein to test their ability to perturb gap-junctional intercellular communication in mouse embryos. It was found that injection of anti-peptide antibodies designed to the cytoplasmic loop of Cx43, together with the dyes Lucifer Yellow or Cascade Blue, was effective in blocking the transfer of dye between blastomeres of 8-16-cell embryos. In addition, the cell containing the blocking antibody decompacted and was excluded from further development (Becker et al. 1995), suggesting that good gap-junctional communication is essential for compaction and embryo development (Becker \& Davies 1995).

These experiments may be interpreted in light of the results obtained from Cx43-null homozygous mutant embryos, which develop normally and establish full-term pregnancies (Reaume et al. 1995). Embryos lacking Cx43 have been shown to display a severely reduced level of dye coupling with altered permeability characteristics (De Sousa et al. 1997). Thus, Cx43-null homozygous morulae 
were found to be uncoupled when injected with 6-carboxyfluorescein, but when $2^{\prime}, 7^{\prime}$-dichlorofluorescein was used coupling was evident. These permeability characteristics are typical of $\mathrm{Cx} 45$ channels, although the possible involvement of other connexins cannot be ruled out. Gap-junction channels are differentially and selectively permeable to various dyes (Elfgang et al. 1995). This may explain the apparent lack of coupling in embryos injected with anti-Cx43 antibodies using an anionic dye like Lucifer Yellow, which is transmitted poorly in Cx45 channels (Steinberg et al. 1994).

The importance of gap-junctional communication has been studied using the inhibitor $18 \alpha$-glycyrrhetinic acid (AGA), which completely abolished dye coupling in preimplantation embryos without affecting blastocyst formation, or cell allocation to the trophectoderm or inner cell mass (Vance \& Wiley 1999). These results were surprising but suggested that gap-junctional intercellular communication was not required for successful development of the preimplantation embryo. However, it is possible that coupling-deficient embryos display secondary, cellular or metabolic defects since it is known that signalling molecules may be transmitted via gap junctions with implications in cell protection via programmed cell death (Bannerman et al. 2000). However, there was no observable difference in TUNEL (terminal deoxynucleotidyl transferase-mediated dUTP nick-end labelling) staining between AGA-treated and control blastocysts (Houghton et al. 2002). Transport through gap junctions has also been identified as a potential rate-limiting factor in glucose utilization by cultured cells (Giaume et al. 1997). Again this seems not to be the case in the preimplantation embryo since there was no significant difference in glucose and pyruvate consumption and lactate production in blastocysts cultured in the presence or absence of AGA (Houghton et al. 2002). Taken together, these results suggest that gap-junctional intercellular communication is not obligatory for preimplantation development. However, this conclusion should be treated with caution since relatively few reagents are known to block gap-junctional intercellular communication in a specific manner. AGA indirectly blocks gap junctions through activation of protein kinases, G-proteins or transport ATPases (Evans \& Boitano 2001). This causes changes in the phosphorylation of the connexin C-terminal tail, particularly Cx43 and Cx45, affecting channel gating and assembly into functional gap junctions (Evans \& Boitano 2001, Zucker \& Nicholson 2002). Nine connexins are expressed during murine preimplantation development and hence it is difficult to know whether intercellular communication is dispensible, since there are currently no specific inhibitors capable of blocking all the potential types of channel. In addition, although gap junctions may appear dispensible to preimplantation development, the ability of uncoupled blastocysts to produce viable offspring following embryo transfer has yet to be tested.
It is perhaps not surprising that gap junctions do not represent a major conduit for the exchange of metabolites within the preimplantation embryo since most nutrients shown to be taken up in vitro, such as pyruvate, glucose, lactate and amino acids, have specific transporters present in the plasma membrane (Wales \& Whittingham 1967, Leese \& Barton 1984, Gardner \& Leese 1988, Manejwala et al. 1989, Hogan et al. 1991, Wiley et al. 1991, Aghayan et al. 1992, Pantaleon et al. 1997, Butcher et al. 1998, Carayannopoulos et al. 2000, 2004, Van Winkle 2001, Martin et al. 2003).

In summary, controversy still surrounds the functional requirement of gap junctional intercellular communication in the preimplantation embryo. If gap junctions are not obligatory, at least in the mouse, it is legitimate to ask: whether they have some as-yet undiscovered role, perhaps in vivo; whether they are expressed precociously in anticipation of some future event(s); and whether they provide a fail-safe function for contingencies that might arise in vivo.

In response to the first question, the major feature of development in vivo, absent in vitro, is obviously the presence of the maternal compartment. It is likely that embryo-maternal signalling will occur during preimplantation development and that maternally derived molecules will need to be distributed rapidly and evenly between the cells of the early embryo to ensure a consistent response. This homeostatic mechanism would be facilitated by the presence of gap junctions and may contribute to the superiority of in vivo over in vitro development in terms of blastocyst formation rate and cell number (Bowman \& McLaren 1970).

Regarding the second question, it has been proposed that multiple connexins are expressed in the preimplantation embryo to ensure their coordinated and rapid segregation at implantation (Houghton et al. 2002). For example, Cx31 and Cx43 are expressed abundantly in both cell lineages of the blastocyst, the inner cell mass and trophectoderm, but upon implantation Cx31 is restricted to the ectoplacental cone and extraembryonic ectoderm, while $\mathrm{C} \times 43$ is found in the embryo and visceral endoderm (Dahl et al. 1996, Grümmer et al. 1996).

Finally, it is possible that gap junctions are required for the early embryo to respond with maximal efficiency to stresses encountered in vivo, for example, by delayed fertilization, prolonged transit through the Fallopian tube or early entry into the uterus.

\section{Conclusion}

It is difficult to envisage that gap-junctional intercellular communication is not required during preimplantation development, at least for blastocyst formation. The formation of gap junctions during compaction will ensure their presence at cavitation and in the trophectoderm and inner cell mass. The trophectoderm is the first epithelium 
and, by analogy with adult epithelial tissues, acts as a selective entry and exit system to a variety of molecules ultimately required by the cells of the inner cell mass (Brison et al. 1993, Hewitson \& Leese 1993). It is essential that the trophectoderm acts as a functional unit, a role that will be facilitated by the presence of gap junctions to ensure consistency in response to extracellular signals or those derived from the inner cell mass via the blastocoel fluid.

\section{Acknowledgements}

I would like to thank Professor Henry Leese for his critical reading of the manuscript and many helpful discussions. F D $\mathrm{H}$ is supported by a Wellcome Trust Research Career Development Fellowship. The author declares that there is no conflict of interest that would prejudice the impartiality of this scientific work.

\section{References}

Aghayan M, Rao LV, Smith RM, Jarett L, Charron MJ, Thorens B \& Heyner S 1992 Developmental expression and cellular localization of glucose transporter molecules during mouse preimplantation development. Development 115 305-312.

Alves LA, Nihei OK, Fonseca PC, Campos-de-Carvalho AC \& Savino W 2000 Gap junction modulation by extracellular signaling molecules: the thymus model. Brazilian Journal of Medical and Biological Research 33 457-465.

Bannerman P, Nichols W, Puhalla S, Oliver T, Berman M \& Pleasure D 2000 Early migratory rat neural crest cells express functional gap junctions: evidence that neural crest cell survival requires gap junctions function. Journal of Neuroscience Research 61 605-615.

Becker DL \& Davies CS 1995 Role of gap junctions in the development of the preimplantation mouse embryo. Microscopy Research and Technique 31 364-374.

Becker DL, Evans WH, Green CR \& Warner AE 1995 Functional analysis of amino acid sequences in connexin 43 involved in intercellular communication through gap junctions. Journal of Cell Science 108 1455-1467.

Bevans CG, Kordel M, Rhee SK \& Harris AL 1998 Isoform composition of connexin channels determines selectivity among second messengers and uncharged molecules. Journal of Biological Chemistry $2732808-2816$.

Beyer EC, Paul DL \& Goodenough DA 1987 Connexin43: a protein from rat heart homologous to a gap junction protein from liver. Journal of Cell Biology 108 2621-2629.

Bloor DJ, Wilson Y, Kibschull M, Traub O, Leese HJ, Winterhager E \& Kimber SJ 2004 Expression of connexins in human preimplantation embryos in vitro. Reproductive Biology and Endocrinology 2 25.

Bowman P \& McLaren A 1970 Cleavage rate of mouse embryos in vivo and in vitro. Journal of Embryology and Experimental Morphology 24 203-207.

Brison DR, Hewitson LC \& Leese HJ 1993 Glucose, pyruvate and lactate concentrations in the blastocoel cavity of rat and mouse embryos. Molecular Reproduction and Development 35 227-232.

Bruzzone R, White TW \& Goodenough DA 1996a The cellular internet: on-line with connexins. BioEssays 18 709-718.

Bruzzone R, White TW \& Paul DL $1996 b$ connections with connexins: the molecular basis of direct intercellular signaling. European Journal of Biochemistry 238 1-27.

Butcher L, Coates A, Martin KL, Rutherford AJ \& Leese HJ 1998 Metabolism of pyruvate by the early human embryo. Biology of Reproduction 58 1054-1056.
Butterweck A, Gergs U, Elfgang C, Willecke K \& Traub O 1994 Immunochemical characterization of the gap junction protein connexin45 in mouse kidney and transfected human HeLa cells. Journal of Membrane Biology 141 247-256.

Carayannopoulos MO, Chi MM, Cui Y, Pingsterhaus JM, McKnight RA, Mueckler M, Devaskar SU \& Moley KH 2000 GLUT8 is a glucose transporter responsible for insulin-stimulated glucose uptake in the blastocyst. PNAS 97 7313-7318.

Carayannopoulos MO, Schlein A, Wyman A, Chi M, Keembiyehetty C \& Moley KH 2004 GLUT9 is differentially expressed and targeted in the preimplantation embryo. Endocrinology 145 1435-1443.

Casio M, Kumar NM, Safarik R \& Gilula NB 1995 Physical characterization of gap junction membrane connexons (hemi-channels) isolated from rat liver. Journal of Biological Chemistry 270 $18643-18648$.

Dahl E, Winterhager E, Reuss B, Traub O, Butterweck A \& Willecke K 1996 Expression of the gap junction proteins connexin31 and connexin43 correlates with communication compartments in extraembryonic tissues and in the gastrulating mouse embryo, respectively. Journal of Cell Science 109 191-197.

Davies TC, Barr KJ, Holstead Jones D, Zhu D \& Kidder GM 1996 Multiple members of the connexin gene family participate in preimplantation development of the mouse. Developmental Genetics 18 234-243.

Delorme B, Dahl E, Jarry-Guichard T, Briand J-P, Willecke K, Gros D \& Theveniau-Ruissy M 1997 Expression pattern of connexin gene products at the early developmental stages of the mouse cardiovascular system. Circulation Research 81 423-437.

De Sousa PA, Valdimarsson G, Nicholson BJ \& Kidder GM 1993 Connexin trafficking and the control of gap junction assembly in mouse preimplantation embryos. Development 117 1355-1367.

De Sousa PA, Juneja SC, Caveney S, Houghton FD, Davies TC, Reaume AG, Rossant J \& Kidder GM 1997 Normal development of preimplantation mouse embryos deficient in gap junction coupling. Journal of Cell Science 110 1751-1758.

Elfgang C, Eckert R, Lichtenberg-Fraté $\mathbf{H}$, Butterweck A, Traub $\mathbf{O}$, Klein RA, Hülser DF \& Willecke K 1995 Specific permeability and selective formation of gap junction channels in connexintransfected HeLa cells. Journal of Cell Biology 129 805-817.

Evans WH \& Boitano S 2001 Connexin mimetic peptides: specific inhibitors of gap-junctional intercellular communication. Biochemical Society Transactions 29 606-612.

Fleming TP, Sheth B \& Fesenko I 2001 Cell adhesion in the preimplantation mammalian embryo and its role in trophectoderm differentiation and blastocyst morphogenesis. Frontiers in Bioscience $\mathbf{6}$ D1000-D1007.

Gabriel H-D, Jung D, Bützler C, Temme A, Traub O, Winterhager E \& Willecke K 1998 Transplacental uptake of glucose is decreased in embryonic lethal connexin26-deficient mice. Journal of Cell Biology 140 1453-1461.

Gardner DK \& Leese HJ 1988 The role of glucose and pyruvate transport in regulating nutrient utilization by preimplantation mouse embryos. Development 104 423-429.

Giaume C, Tabernero A \& Medinea JM 1997 Metabolic trafficking through astrocytic gap junctions. Glia 21 114-123.

Goldberg GS, Lampe PD \& Nicholson BJ 1999 Selective transfer of endogenous metabolites through gap junctions composed of different connexins. Nature Cell Biology $\mathbf{1}$ 457-459.

Gong X, Li E, Klier G, Huang Q, Wu Y, Lei H, Kumar NM, Horwitz J \& Gilula NB 1997 Disruption of alpha3 connexin gene leads to proteolysis and cataractogenesis in mice. Cell 91 833-843.

Grümmer R, Reuss B \& Winterhager E 1996 Expression pattern of different gap junction connexins is related to embryo implantation. International Journal of Developmental Biology $\mathbf{4 0}$ $361-367$.

Guldenagel M, Ammermuller J, Feigenspan A, Teubner B, Degen J, Sohl G, Willecke K \& Weiler R 2001 Visual transmission deficits in 
mice with targeted disruption of the gap junction gene connexin36. Journal of Neuroscience 21 6036-6044.

Hardy K, Warner A, Winston RM \& Becker DL 1996 Expression of intercellular junctions during preimplantation development of the human embryo. Molecular Human Reproduction 2 621-632.

Hewitson LC \& Leese HJ 1993 Energy metabolism of the trophectoderm and inner cell mass of the mouse blastocyst. Journal of Experimental Zoology 267 337-343.

Hogan A, Heyner S, Charron MJ, Copeland NG, Gilbert DJ, Jenkins NA, Thorens B \& Schultz GA 1991 Glucose tranporter gene expression in early mouse embryos. Development 113 363-372.

Hoh JH, Sosinsky GE, Revel JP \& Hansma PK 1993 Structure of the extracellular surface of the gap junction by atomic force microscopy. Biophysical Journal 65 149-163.

Houghton FD, Thonnissen E, Kidder GM, Naus CCG, Willecke K \& Winterhager E 1999 Doubly mutant mice, deficient in connexin32 and -43 , show normal prenatal development of organs where the two gap junction proteins are expressed in the same cells. Developmental Genetics 24 5-12.

Houghton FD, Barr KJ, Walter G, Gabriel H-D, Grümmer R, Traub O, Leese HJ \& Kidder GM 2002 Functional significance of gap junctional coupling in preimplantation development. Biology of Reproduction 66 1403-1412.

Jongen WM, Fitzgerald DJ, Asamoto M, Piccoli C, Slaga TJ, Gros D, Takeichi M \& Yamasaki H 1991 Regulation of connexin 43mediated gap junctional intercellular communication by $\mathrm{Ca} 2+$ in mouse epidermal cells is controlled by E-cadherin. Journal of Cell Biology 114 545-555.

Kidder GM, Rains J \& McKeon J 1987 Gap junction assembly in the preimplantation mouse conceptus is independent of microtubules, microfilaments, cell flattening and cytokinesis. PNAS $\mathbf{8 4}$ 3718-3722.

Koval M 2002 Sharing signals: connecting lung epithelial cells with gap junction channels. American Journal of Physiology Lung Cellular and Molecular Physiology 283 L875-L893.

Kumai M, Nishii K, Nakamura K, Takeda N, Suzuki M \& Shibata Y 2000 Loss of connexin45 causes a cushion defect in early cardiogenesis. Development 127 3501-3512.

Kwak BR, Van Veen TBA, Analbers LJS \& Jongsma HJ 1995 TPA increases conductance but decreases permeability in neonatal rat cardiomyocyte gap junction channels. Experimental Cell Research 220 456-463.

Lal R, John SA, Laird DW \& Arnsdorf MF 1995 Heart gap junction preparations reveal hemiplaques by atomic force microscopy. American Journal of Physiology Cellular Physiology 268 C968-C977.

Lampe PD \& Lau AF 2004 The effects of connexin phosphorylation on gap junctional communication. International Journal of Biochemistry and Cell Biology 36 1171-1186.

Leese HJ \& Barton AM 1984 Pyruvate and glucose uptake by mouse ova and preimplantation embryos. Journal of Reproduction and Fertility 72 9-13.

Lonergan P, Rizos D, Gutiérrez-Adán A, Moreira PM, Pintado B, de la Fuente J \& Boland MP 2003 Temporal divergence in the pattern of messenger RNA expression in bovine embryos cultured from the zygote to blastocyst stage in vitro or in vivo. Biology of Reproduction 69 1424-1431.

Makowski L, Casper DLD, Phillips WC \& Goodenough DA 1977 Gap junction structures. II. Analysis of the x-ray diffraction data. Journal of Cell Biology 74 629-645.

Manejwala FM, Cragoe EJ \& Schultz RM 1989 Blastocoel expansion in the preimplantation mouse embryo: role of extracellular sodium and chloride and possible apical routes of their entry. Developmental Biology 133 210-220.

Martin PM, Sutherland AE \& Van Winkle LJ 2003 Amino acid transport regulates blastocyst implantation. Biology of Reproduction 69 $1101-1108$.

Mege RM, Matsuzaki F, Gallin WF, Goldberg JI, Cunningham BA \& Edelman GM 1988 Construction of epithelioid sheets by tranfection of mouse sarcoma cells with cDNAs for chicken cell adhesion molecules. PNAS 85 7274-7278.

Musil LS, Cunningham BA, Edelman GM \& Goodenough DA 1990 Differential phosphorylation of the gap junction protein connexin43 in junctional communication-competent and deficient cell lines. Journal of Cell Biology 111 2077-2088.

Nelles E, Butzler C, Jung D, Temme A, Gabriel HD, Dahl U, Traub O, Stumpel F, Jungermann K, Zielasek J et al. 1996 Defective propagation of signals generated by sympathetic nerve stimulation in the liver of connexin32-deficient mice. PNAS 93 9565-9570.

Nicholson SM \& Bruzzone R 1997 Gap junctions: getting the message through. Current Biology 7 R340-R344.

Nicholson B, Dermietzel R, Teplow D, Traub O, Willecke K \& Revel J-P 1987 Two homologous protein components of hepatic gap junctions. Nature $329732-734$.

Ogawa H, Oyamada M, Mori T, Mori M \& Shimizu H 2000 Relationship of gap junction formation to phosphorylation of connexin43 in mouse preimplantation embryos. Molecular Reproduction and Development 55 393-398.

Pantaleon M, Harvey MB, Pascoe WS, James JE \& Kaye PL 1997 GLUT3: ontogeny, targeting and role in blastocyst formation. PNAS 94 3795-3800.

Plum A, Winterhager E, Pesch J, Lautermann J, Hallas G, Rosentreter B, Traub O, Herberhold C \& Willecke K 2001 Connexin31deficiency in mice causes transient placental dysmorphogenesis but does not impair hearing and skin differentiation. Developmental Biology 231 334-347.

Reaume AG, De Sousa PA, Kulkarni S, Langille BL, Zhu D, Davies TC, Juneja SC, Kidder GM \& Rossant J 1995 Cardiac malformation in neonatal mice lacking connexin43. Science $\mathbf{2 6 7}$ 1831-1834.

Revel JP \& Karnovsky MJ 1967 Hexagonal array of subunits in intercellular junctions of the mouse heart and liver. Journal of Cell Biology 33 C7-C12.

Reynhout JK, Lampe PD \& Johnson RG 1992 An activator of protein kinase $C$ inhibits gap junction communication between cultured bovine lens cells. Experimental Cell Research 198 337-342.

Sáez JC, Martinez AD, Brañes MC \& González HE 1998 Regulation of gap junctions by protein phosphorylation. Brazilian Journal of Medical and Biological Research 31 593-600.

Simon AM, Goodenough DA, Li E \& Paul DL 1997 Female infertility in mice lacking connexin 37. Nature 385 525-529.

Simon AM, Goodenough DA \& Paul DL 1998 Mice lacking connexin 40 have cardiac conduction abnormalities characteristic of atrioventricular block and bundle branch block. Current Biology 8 295-298.

Stagg RB \& Fletcher WH 1990 The hormone-induced regulation of contact-dependent cell-cell communication by phosphorylation. Endocrine Reviews 11 302-325.

Steinberg TH, Civitelli R, Geist ST, Robertson AJ, Hick E, Veenstra RD, Wang H-Z, Warlow PM, Westphale EM, Laing JG \& Beyer EC 1994 Connexin43 and connexin45 form gap junctions with different molecular permeabilities in osteoblastic cells. $E M B O$ Journal 13 744-750.

Teubner B, Michel V, Pesch J, Lautermann J, Cohen-Salmon M, Sohl G, Jahnke K, Winterhager E, Herberhold C, Hardelin JP et al. 2003 Connexin30 (Gjb6)-deficiency causes severe hearing impairment and lack of endocochlear potential. Human Molecular Genetics 12 13-21.

Unwin PN \& Zampighi G 1980 Structure of the junction between communicating cells. Nature 283 545-549.

Vance MM \& Wiley LM 1999 Gap junction intercellular communication mediates the competitive cell proliferation disadvantage of irradiated mouse preimplantation embryos in aggregation chimeras. Radiation Research 152 544-551.

Van Winkle LJ 2001 Amino acid transport regulation and early embryo development. Biology of Reproduction 64 1-12. 
Wales RG \& Whittingham DG 1967 A comparison of the uptake and utilisation of lactate and pyruvate by one- and two-cell mouse embryos. Biochimica Biophysica Acta 148 703-712.

White TW \& Paul DL 1999 Genetic diseases and gene knockouts reveal diverse connexin functions. Annual Review of Physiology $61283-310$.

White TW, Goodenough DA \& Paul DL 1998 Targeted ablation of connexin50 in mice results in microphthalmia and zonular pulverulent cataracts. Journal of Cell Biology 143 815-825.

Wiley LM, Lever JE, Pape C \& Kidder GM 1991 Antibodies to a renal $\mathrm{Na}+$ /glucose cotransport system localize to the apical plasma membrane domain of polar mouse embryo blastomeres. Developmental Biology 143 149-161.

Willecke K, Eiberger J, Degen J, Eckardt D, Romualdi A, Guldenagel M, Deutsch U \& Sohl G 2002 Structural and functional diversity of connexin genes in the mouse and human genome. Biological Chemistry 383 725-737.

Wrenzycki C, Herrmann JW, Carnwath JW \& Niemann H 1996 Expression of the gap junction gene connexin43 (Cx43) in preimplantation bovine embryos derived in vitro and in vivo. Journal of Reproduction and Fertility 108 17-24.

Zucker S \& Nicholson BJ 2002 Mutagenic approaches to modifying gap junction phenotype. Current Drug Targets 3 441-453.

Received 15 April 2004

First decision 18 May 2004

Revised manuscript received 16 November 2004

Accepted 22 November 2004 